\title{
Developing an Assessment Instrument for Indonesian EFL Teachers' Performance Based on the Students' Perceptions
}

\author{
Haryanto Atmowardoyo ${ }^{1}, \mathbf{J a}^{\prime}$ faruddin $^{2}$, Khaerati $^{3}$ \\ State University of Makassar, Indonesia \\ State University of Makassar, Indonesia
}

STKIP Pembangunan Indonesia Makassar, Indonesia

\begin{abstract}
The absence of an instrument specifically usable to measure Indonesian EFL Teachers' performance has inspired the researchers to develop a valid and reliable instrument based on the students' perceptions. A two-phase research activity has been conducted to reveal a newly developed instrument. The first research has been conducted to identify the qualities an effective Indonesian EFL Teacher should possess, and the weak points an ineffective Indonesian EFL Teacher performs during his or her classroom teaching. A think-aloud technique of data collection was used, whereby 86 first year semester students of English Department were asked to report their educational experiences in learning English with favorable and unfavorable EFL teachers. A number of qualities for an effective EFL teacher and a number of weak points for an ineffective EFL teacher were identified from their reports through a coding process. Based on the identified qualities and weak points, a questionnaire draft is developed. The draft was then scholarly validated and, then, tested to 100 senior high school students to find out its reliability index. Finally, the researchers successfully reveal a 44 itemquestionnaire with reliability index of 90.4. This indicates that the newly developed instrument is valid and reliable to measure Indonesian EFL Teachers' performance. With this instrument, school management is recommended to use the instrument to assess their Indonesian EFL teachers' performance.
\end{abstract}

Keywords: assessment instrument, Indonesian EFL Teacher, students' perception

\section{Introduction}

A classical motto maintains that organizational management comprises four levels of important jobs: planning, organizing, acting, and evaluating. From these levels, however, we shall focus on the last: Evaluating. In the field of TEFL (the teaching of English as a foreign language), evaluating activity involves assessing job performance of the main actors: English language teachers.

Teachers have important roles in the success of curriculum implementation because on the teacher's hand, the curriculum is analyzed, designed, adapted then implemented in the teaching process at school. Besides, the teacher's attitude influences the students' attitude and character at school and especially in the classroom. Therefore, the teacher also has an important role in modeling the students' character. Generally, the teacher's assessment is conducted by the school management to improve or maintain their work performance. The stake holder called "students", then, is considered as the one who knows the best about their teachers' performance. Thus, it is considered important to hear from the students as the "users" who have direct interaction with the teacher in the classroom about their perceptions and opinion on their teachers' performance.

\section{Study 1}

A study on the students' perception about effective and ineffective EFL teachers has been conducted by Atmowardoyo et al (2016). This study was designed to investigate the students' perception about qualities of effective and ineffective EFL teachers. A total of 86 freshmen of English Department, State University of
Makassar were assigned to report their learning experiences with their favorite EFL teachers as well as with their disliked EFL teachers. Their reports were analyzed through the process of coding adapted from Strauss and Corbin (1990). This process consists of three steps: open coding, axial coding, and selective coding. This study has revealed a list of characteristics attributable to effective EFL teachers as well as a list of characteristics for ineffective EFL teachers. Both lists of characteristics have been reported on an International Conference in Harvard University (2106).

\section{Study 2}

The result of Study 1 has inspired us to make use of that important information to develop an assessment of EFL teachers' performance. What is reported here is the process of making use of the list to become a valid and reliable instrument usable to measure on which degree an EFL teacher is effective. This has been conducted through a research and development activity. The main focus of this research is to develop an instrument to assess the English teacher's performance. While the secondary objectives are to obtain information about a certain model of an instrument which can be used to measure the performance of English teachers based on the students' perceptions; and the level of the instrument validity and reliability to measure the performance of English teachers based on the students' perceptions.

Concerning that focus, the research questions were formulated as follow:

a) What is the model of instrument to measure the performance of English teachers based on the students' perceptions?

\section{Volume 6 Issue 7, July 2017}




\section{International Journal of Science and Research (IJSR) \\ ISSN (Online): 2319-7064}

Index Copernicus Value (2015): 78.96 | Impact Factor (2015): 6.391

b) How consistent is the model in measuring the performance of English teachers based on the students' perceptions?

c) Is the instrument in measuring the performance of English teachers based on the students' perceptions valid and reliable?

\section{Related Concepts}

\section{Effective vs Ineffective Teacher}

Adams and Pierce (2006) define the effective teacher as the teachers' ability to adjust the material with the students' need and ability to organize the material to facilitate the learning, communicate effectively, deciding the goal specifically, find the appropriate method to reach the goal of teaching and learning.

Furthermore Neil (1991) states that effective teachers must possess a professional knowledge base and exhibit knowledge of the subject and techniques that reflect their knowledge of the subject.

According to Walls et al. (2002), some characteristics of ineffective teachers include: (1) discouraged questions, (2) authoritarian and controlling of the learning environment, (3) had favorites in the class, (4) not visible throughout the class, (5) highly disorganized, (6) focuses on vicarious learning, (7) controlling, and (8) lacks classroom management skills

Metimukarrama (2014) conducted a research and found out that an ideal teacher should master the four teacher competencies and have a good physical appearance. In addition, Leslie (2013) conducted a research under the title Effective vs. Ineffective Teachers Educating our Children and found out that the main components of effective teaching are analytical system approach, organizational/clarity, instructor/ group interaction, instructor individual students' interaction, and dynamism/ enthusiasm.

Another study that is closely related to this is Khaerati (2016). This study is designed to reveal the characteristics of effective EFL teachers and ineffective EFL teachers. She has reported a number of characteristics of effective EFL teachers and ineffective EFL teachers.

\section{Research Method}

The research design taken for this study is Research and Development. Adapted from Tiro and Sukarna (2012), the procedure of this research and development is described in seven steps as follows:

\section{1) Identifying problems}

Under this step, a problem is identified. Educational management do assess their teachers by sending supervisors to observe teachers' work performance. Assessment of this kind is not sufficient due to their subjectivity. Another way of assessment should be conducted. Students are considered as the important stake holders who have the capacity to judge whether or not their teachers are effective. However, from the literature review, an instrument specially used to measure the effectiveness of an EFL teacher is not yet available. This leads to the necessity for developing an assessment instrument based on the students' perception.

\section{2) Collecting Information}

Under this step, students' perception on the characteristics of effective EFL teachers as well as those of ineffective EFL teachers is collected. This information is taken from Study 1 by Atmowardoyo et al (2016). Two lists of characteristics of EFL teachers are collected. The first list contains a number of characteristics of effective EFL teachers based on the students' perception. The second is a list of characteristics of ineffective EFL teachers.

\section{3) Designing the preliminary draft}

Based on the identified problems and collected information, a preliminary draft of an assessment instrument is designed. The draft consists of 50 items describing characteristics of effective and ineffective EFL teachers.

\section{4) Validating the draft through Expert Validation}

This stage is an activity process to assess whether the instrument draft is readable and relevant to measure EFL teachers' performance. Validation is done by presenting the draft to experts in educational evaluation and experienced EFL professionals.

\section{5) Revising the draft}

After validation through discussions with experts or experts, a revision is done to minimize the weaknesses. Items which are not relevant are delineated; those which are not clear are revised. As a result a questionnaire with 50 items is yielded.

\section{6) Testing the revised draft}

The revised draft is then tested in one school by selecting 100 students of a vocational senior high school in Makassar as the respondents. An SPSS program is used to find out the Cronbach Alpha value used to see the consistency level of the draft.

\section{7) Finishing the daft}

The last step is to finalize the instrument draft. Under this step, some items are delineated since they are not consistent. A total number of 44 items, however, are selected since they are consistent with reliability index of 90.4, which means highly reliable. The questionnaire consists of 20 characteristics for effective EFL teachers, and 24 characteristics of ineffective EFL teachers. The final draft is therefore, a questionnaire containing 44 statements to be judged by the students. Twenty items are of positive statements; and twenty four items are of negative statements.

\section{Findings and Discussion}

\section{Study 1}

It has been mentioned before that the study is a continuation of study 1 reported by Atmowardoyo et.al. (2016) This study has revealed a list of characteristics for effective EFL teachers as well as a list of those of ieffective EFL teachers. The lists include characteristics as follows:

\section{Effective EFL Teachers tend to:}

1. be patient.

2. be strict and discipline. 
3. be humorous

4. be friendly

5. be kind.

6. be wise.

7. forgive and advise students.

8. be punctual

9. be responsible.

10. love teaching.

11. master the taught material

12. have a correct pronunciation.

13. teach based on the curriculum.

14. understand the students' ability.

15. understand the students' characters.

16. let the students know the objective of the lesson.

17. conduct a pre-test.

18. prepare a lesson plan.

19. support the students to be brave and confident.

20. motivate the students.

21. know how to make an ice break.

22. explain the material clearly.

23. use code switching sometimes.

24. combine theory and practice.

25. use appropriate media in teaching.

26. encourage the students to be active in the classroom.

27. improve students' speaking skill.

28. improve students' vocabulary.

29. teach systematically.

30. know when to give assignment.

31. teach the four skills.

32. demonstrate fun teaching method.

33. teach grammar effectively.

34. make the students enthusiastic and interested in english

35. challenge the students.

36. make the classroom atmosphere comfortable.

37. involve the students in a group discussion.

38. encourage students to join at the english competition.

39. be appreciative.

40. assign the students to memorize the vocabulary.

41. give the students a chance to ask question.

42. repeat the explanation.

43. be creative.

44. correct the students' mistake.

45. check the students' homework or assignment.

46. score and grade the students' work.

\section{Ineffective EFL Teachers, on the other hand, tend to:}

1. come late

2. be indiscipline.

3 . be unfriendly.

4. easily get angry

5. be weak.

6. neglect students

7. show incompetence of the material taught.

8. be lack of vocabulary.

9. teach english if it is not your major.

10. neglect a lesson plan.

11. have unwell prepared material .

12. teach merely based on the textbook.

13. neglect the students' ability.

14. neglect the students' character

15. demonstrate a boring teaching method

16. leave the material unexplained

17. neglect explaining about the grammar
18. explain the material too fast

19. leave the students during teaching and learning

20. use english rarely

21. use english all the time in the classroom

22. give too many assignments to the students

23. neglect appreciating the students' work

24. talk too much

25 . have a very low voice

26. neglect giving chances to the students to practice

27. have a bad communication skill

28. neglect correcting the students' mistake

29. be passive in the classroom

30. assign the students to memorize vocabulary leave the homework or assignment unchecked

31. be unfair in scoring or grading.

32. discriminate the students.

33. focus on some certain students

34. punish the students physically.

35. compare one student to another.

\section{Study 2}

The ultimate product of the research is an assessment instrument in which in the form of questionnaire usable to measure the performance of English teachers. This instrument measures indicators that include 44 items of statements consisting of 20 positive statements and 24 negative statements. The instrument that has been developed has content validity as $98 \%$ which means that instrument is valid while the reliability value is Alpha Cronbach 90.4\% which means that instrument is highly reliable. The product is enclosed as an appendix.

\section{Conclusion and Suggestions}

This study has revealed an assessement instrument to measure the effectiveness level of EFL teachers based on the students' perception. A questionnaire consisting 20 positive staements and 24 negative sttatements is declated valid and reliable. With this newly developed instrument, school management may be helped in evaluating their EFL teachers. Researchers seeking for information about how effective EFL teachers in an educational setting may also be helped when using this instrument. In short, this instrument will be beneficial for teachers and those who are in charged in making decision in education to increase the quality of English education in Indonesia, as well as researchers dealing with TEFL quality.

\section{Acknowledgements}

Haryanto Atmowardoyo is a professor in English Language Education, State University of Makassar. Ja'faruddin is a lecturer at Mathematics Department, and Kaherati is a graduate student in English Education Program. The research is funded by Non Tax State Revenue of the Graduate Program, State University of Makassar. We, therefore, would like to thank Professor Jasruddin, the Graduate Program Director, and professor Husain Syam, the Rector of the State University of Makassar. 


\section{International Journal of Science and Research (IJSR) \\ ISSN (Online): 2319-7064}

Index Copernicus Value (2015): 78.96 | Impact Factor (2015): 6.391

\section{References}

[1] Adams, Cheryll M, and Rebecca L. Pierce. 2006. Characteristics of Effective Teaching. [online]. Available. (http://www.lingofest.com/.../ Characteristics\%20of\%20effective\%20 teaching.pdf). Accessed on May 11, 2013.

[2] Atmowardoyo, H., Khaerati, Hamra, A. 2016. Learners' Perception about Effective vs. Ineffective EFL Teachers' Personal and Professional Competences, in Change the World, Conference Program Book, Oral Presentations in the Forth $21^{\text {st }}$ Century Academic Forum, Harvard University, 20-23 March 2016.

[3] Khaerati, K. (2016). The Students' Perception on the Characteristics of Effective and Ineffective English Language Teachers. ELT WORLDWIDE, 3(2), 221-230.

[4] Leslie, Johnson, Natalie A. (2013) Effective vs. Ineffective Teachers Educating our Children. Arkansas State University, United States of America
[5] Metimukarrama. 2014. How the Students Perceive the Ideal Teachers of English: A Descriptive-Reflective Study at Senior High School in Pangkep regency. Thesis. Pasca Sarjana. UNM. unpublished.

[6] Strauss, Anselm and Juliet Corbin, 1990. Basis of Qualitative Research : Procedures and Techniques of Grounded Theory. New York : Sage Publications

[7] Tiro, Muhammad A \& Sukarna. 2012. Pengembangan Instrument Pengumpulan Data Penelitian. Andira Publisher Makassar: Makassar.

[8] Walls, Richard T., Anne H. Nardi, Avril M. Von Minden and Nancy Hoffman. 2002."The Characteristics of Effective and Ineffective Teachers". Teacher EducationQuarterly, 29(1), 39.[Online]

Available.(http://www.teqjournal) .rg/Back\%20Issues/Volume\%2029/VOL29\%20PDFS 129_1/w02_walls_nardi-29_1.pdf. Accessed on June, 2013.

\section{Appendix \\ THE NEWLY DEVELOPED ASSESSMENT INSTRUMENT OF INDONESIAN EFL TEACHERS' PERFORMANCE BASED ON STUDENT'S PERCEPTION}

Developed by: Haryanto Atmowardoyo, Khaerati, Ja'faruddin (2016)

Name of Teacher:

Directions: (Petunjuk:)

Dear students, please recall the way how your English teacher teaches you. Give the scores for him/her by reading the following 44 statements and circle the score under every statement for him/her based on your perception. Score 1 means "strongly disagree"; score 2 means "disagree"; score 3 means "agree", or score 4 means "strongly agree".

(Siswa yang terhormat, cobalah ingat-ingat bagaimana guru bahasa Inggris Anda mengajar Anda. Beri nilai untuk dia dengan membaca 44 pernyataan berikut dan melingkari skor di bawah setiap pernyataan untuknya berdasarkan persepsi Anda. Skor 1 berarti "sangat tidak setuju"; Skor 2 berarti "tidak setuju"; Skor 3 berarti "setuju", atau skor 4 berarti "sangat setuju".)

1. The teacher uses English well and fluently, writes correctly, and masters the English grammar well. (Guru menggunakan bahasa Inggris dengan baik dan lancar, menulis dengan benar, serta menguasai tata bahasa Inggris dengan baik.)

$$
1 \quad 2 \quad 3 \quad 4
$$

2. The teacher performs innovative and varied learning. (Guru melakukan pembelajaran yang inovatif dan variatif.)

3. The teacher uses clear learning steps. (Guru menggunakan langkah-langkah pembelajaran yang jelas.)

$$
\begin{array}{llll}
1 & 2 & 3 & 4
\end{array}
$$

4. The teacher knows the student's learning needs and knows how to recognize the student's abilities. (Guru mengetahui kebutuhan belajar siswa dan mengetahui cara mengenali kemampuan siswa.)

$$
1 \quad 2 \quad 3 \quad 4
$$

5. The teacher delivers the material clearly, simply, and systematically. (Guru menyampaikan materi secara jelas dan sederhana dan sistematis.)

$1 \quad 2 \quad 3 \quad 4$

6. The teacher provides speaking and writing exercises in English. (Guru memberikan latihan berbicara dan menulis dalam bahasa Inggris.)

$1 \quad 2 \quad 3 \quad 4$

7. The teacher's way of teaching is accompanied by ice breakers and jokes. (Guru mengajar yang disertai dengan ice breaker dan lelucon.)

$\begin{array}{llll}1 & 2 & 3 & 4\end{array}$

Volume 6 Issue 7, July 2017 www.ijsr.net 


\section{International Journal of Science and Research (IJSR) \\ ISSN (Online): 2319-7064}

Index Copernicus Value (2015): 78.96 | Impact Factor (2015): 6.391

8. The teacher always motivates students in every lesson to be always enthusiastic, including encouraging students to be able to memorize new words and use them in conversation. (Guru selalu memotivasi siswa dalam setiap pembelajaran untuk selalu antusias, termasuk mendorong siswa untuk dapat menghapal kata-kata baru dan menggunakannya dalam percakapan.)

9. The teacher teaches in a hurry. (Guru mengajar dengan terburu-buru.)

10. The teacher uses electronic media in the form of movies or song in learning. (Guru menggukan media elektronik berupa film atau lagu dalam pembelajaran.)

$1 \quad 2 \quad 3 \quad 4$

11. The teacher always makes the class interactive and familiar atmosphere. (Guru selalu membuat kelas menjadi interaktif dan suasana akrab.)

$1 \quad 2 \quad 3 \quad 4$

12. The teacher provides examples, appropriate solutions, and appropriate feedback on students' questions. (Guru memberikan contoh dan memberikan solusi dan umpan balik yang tepat terhadap pertanyaan siswa.)
1
23
4

13. The teacher assigns tasks to students in creative and imaginative forms such as making dramas, poetry, etc. (Guru memberikan tugas kepada siswa dalam bentuk yang kreatif dan imajinatif seperti membuat drama, puisi dll.)

$1 \quad 2 \quad 3 \quad 4$

14. The teacher is fair in scoring and providing feedback on the students' work. (Guru adil dalam pemberian nilai dan memberikan umpan balik terhadap pekerjaan siswa.)

$1 \quad 2 \quad 3 \quad 4$

15. The teacher is well-dressed, and looks handsome/beautiful. (Guru berpenmpilan menarik seperti berpakaian rapih, tampan/cantik.)

$1 \quad 2 \quad 3 \quad 4$

16. The teacher shows positive attitudes, wisdoms, funs and affections to students. (Guru mempunyai sikap, bijaksana, menyenangkan serta memperlihatkan kasih sayang kepada siswa.)

$$
1 \quad 2 \quad 3 \quad 4
$$

17. The teacher can control emotions at times that are not fun. (Guru dapat mengontorol emosi pada saat yang tidak menyenangkan.)

$$
1 \quad 2 \quad 3 \quad 4
$$

18. Teacher shows a cheerful attitude. (Guru menunjukkan sikap yang riang.)

$\begin{array}{llll}1 & 2 & 3 & 4\end{array}$

19. The teacher exhibits an attitude that can be emulated by the students. (Guru memperlihatkan sikap yang dapat dicontoh oleh siswa/siswi.)

$$
1 \quad 2 \quad 3 \quad 4
$$

20. The teacher has high dedication. (Guru mempunyai dedikasi yang tinggi.)

$\begin{array}{llll}1 & 2 & 3 & 4\end{array}$

21. The teacher is cheerful and easily smiles. (Guru bersikap riang dan murah senyum.)

$$
\begin{array}{llll}
1 & 2 & 3 & 4
\end{array}
$$

22. The teacher explains materials by reading the text-book. (Guru menjelaskan materi dengan membaca buku teks.)

$$
1 \quad 2 \quad 3 \quad 4
$$

23. The teacher has an inaccurate pronunciation. (Guru mempunyai pengucapan yang tidaktepat.)

$1 \quad 2 \quad 3 \quad 4$

24. The teacher uses the Indonesian language as the instructional language instead of the target language. (Guru menggunakan bahasa Indonesia pada saat pembelajaran.)

Volume 6 Issue 7, July 2017 www.ijsr.net 


\section{International Journal of Science and Research (IJSR) \\ ISSN (Online): 2319-7064}

Index Copernicus Value (2015): 78.96 | Impact Factor (2015): 6.391

$\begin{array}{llll}1 & 2 & 3 & 4\end{array}$

25. The teacher cares on the students' mistakes, but he/she does not convey a clear and precise solution. (Guru peduli pada kesalahan siswa, tetapi tidak memberikan solusi yang jelas dan tepat.)

$\begin{array}{llll}1 & 2 & 3 & 4\end{array}$

26. The teacher gives assignments without explaining the material. (Guru memberikan tugas tanpa menjelaskan materinya.)

$1 \quad 2 \quad 3 \quad 4$

27. The teacher smokes in the classroom. (Guru merokok di dalam kelas.)

$\begin{array}{llll}1 & 2 & 3 & 4\end{array}$

28. The teacher keeps on sitting while explaining the subject matter in the classroom. (Guru duduk pada saat menjelaskan materi pelajaran di dalam kelas.)

$\begin{array}{llll}1 & 2 & 3 & 4\end{array}$

29. The teacher only focuses on grammar. (Guru hanya fokus pada grammar.)

$\begin{array}{llll}1 & 2 & 3 & 4\end{array}$

30. Teacher does not give sufficient subject matter explanation. (Guru menjelaskan materi pelajaran dengan tidak sempurna.) $\begin{array}{llll}1 & 2 & 3 & 4\end{array}$

31. The teacher imposes his/her wish on the students without considering the students' opinions. (Guru memaksakan keinginannya pada siswa tanpa mengetahui pendapat siswa.)

$$
\begin{array}{llll}
1 & 2 & 3 & 4
\end{array}
$$

32. The teacher does not care about students. (Guru tidak peduli terhadap siswa.)

$\begin{array}{llll}1 & 2 & 3 & 4\end{array}$

33. The teacher never teaches in class. (Guru tidak pernah mengajar di dalam kelas.)

$\begin{array}{llll}1 & 2 & 3 & 4\end{array}$

34. The teacher gives too many assignments and never discusses them. (Guru memberikan tugas terlalu banyak dan tidak pernah membahasnya.)

$$
\begin{array}{llll}
1 & 2 & 3 & 4
\end{array}
$$

35. The teacher gets so angry if the student cannot do the task. (Guru sangat marah jika siswa tidak dapat mengerjakan tugas.)

$$
1 \quad 2 \quad 3 \quad 4
$$

36. The teacher seldom explains the correct sentences. (Guru jarang menjelaskan tentang kalimat yang benar.)

$$
1 \quad 2 \quad 3 \quad 4
$$

37. The teacher always asks students to write without practicing other skills such as, speaking, listening. (Guru selalu meminta siswa menulis tanpa mempraktekkan keterampilan lain seperti, berbicara, mendengarkan.)

$$
1 \quad 2 \quad 3 \quad 4
$$

38. The teacher only focuses on smart students. (Guru hanya focus pada siswa yang pintar.)

$$
1 \quad 2 \quad 3 \quad 4
$$

39. The teacher left his students in class. (Guru meninggalkan siswanya dalam kelas.)

$\begin{array}{lllr}1 & 2 & 3 & 4\end{array}$

40. The teacher dresses poorly and badly. (Guru berbusana kurang sopan dan cara berpakaian berpakaiannya buruk.)

$$
\begin{array}{llll}
1 & 2 & 3 & 4
\end{array}
$$

41. The teacher shows childish attitudes. (Guru bersikap kekanak-kanakan.)

$\begin{array}{llll}1 & 2 & 3 & 4\end{array}$

42. The teacher gives negative labels to students like "stupid" or other labels. (Guru memberi label negatif pada siswa seperti "bodoh" atau sejenisnya.)

$1 \quad 2 \quad 3 \quad 4$

Volume 6 Issue 7, July 2017 www.ijsr.net 


\section{International Journal of Science and Research (IJSR) \\ ISSN (Online): 2319-7064}

Index Copernicus Value (2015): 78.96 | Impact Factor (2015): 6.391

43. Teacher creates a tensed classroom atmosphere. (Guru membuat suasana kelas menegangkan.)

$$
1 \quad 2 \quad 3 \quad 4
$$

44. The teacher does not care whether students pay attention or not during explaining the material, and makes the students sleepy. (Guru tidak peduli apakah siswa memperhatikan atau tidak pada saat menjelaskan dan membuat siswa mengantuk.)

$1 \quad 2 \quad 3 \quad 4$

Notes:

Scoring Information

- The questionnaires consist of 20 Positive Statements (PS) numbers 1-20; and 24 Negative Statements (NS) numbers 2144.

- For PS, the scores $1=1 ; 2=2 ; 3=3$; and $4=4$. The score obtained by the teacher from PS ranges from 20 to 80 .

- $\quad$ For NS, the scores $1=4 ; 2=3 ; 3=2$; and $4=1$. Teacher scores range from 24 to 96

- $\quad$ Both scores will be summed, and will range from 44-176.

- $\quad$ The sum is divided by 2 to obtain the final score.

- $\quad$ The final score will range from 22 to 88.

- Example: Teacher A gets scores PS 60 and NS 70. The final score is $60+70=130 / 2=65$ (effective).

- The score is categorized as follows:

- $72-88=$ very effective

- $55-71=$ effective

- $38-54=$ ineffective

- $22-37$ = very ineffective

Volume 6 Issue 7, July 2017 www.ijsr.net 